\title{
Economic driving force: An Analysis of Rock Climbing Tourism in developed countries
}

\author{
CUI Qianru ${ }^{1}$, LI Yuan ${ }^{1,2^{*}}$ \\ ${ }^{1}$ Department of Physical Education, China University of Geosciences, Wuhan 430074, China \\ ${ }^{2}$ Postdoctoral Research Station, China University of Geosciences, Wuhan 430074, China
}

\begin{abstract}
Rock climbing tourism has been valuable for the sustainable development of the rural outdoor economy in developed countries, which is one of the important trends of rock climbing development. The present study reviews the literature and performs comparative analysis to analyze the development status and experience characteristics of rock climbing tourism in developed countries. Research shows: In developed countries such as Britain, the United States, Germany, France, the climbing population continues to grow, and the rock climbing tourism industry has gradually become an important economic driving force to promote the development of rural and mountainous areas. By clarifying the main characteristics of developed countries in the development of rock climbing tourism, this paper aims to provide reference for the development of rock climbing tourism in developing countries and promote the sustainable development of rock climbing tourism industry.
\end{abstract}

\section{Introduction}

With economic and social development, outdoor and adventure tourism based on outdoor sports, such as hiking, mountaineering, diving, and skiing, is becoming the fastest growing tourism sector [1]. Rock climbing is a sport that is closely connected with natural landforms, and it is an important component of promoting the development of sports tourism. Since the 1990s, the number of rock climbers has increased significantly across various countries, and the number of regular participants reaching 44.5 million worldwide [2], with nearly one million rock climbing routes have been established across major mountain ranges around the world. The entry of rock climbing as a sport into the Olympics in 2016 promoted the rapid development of rock climbing, with the development of new opportunities for rock climbing tourism. Rock climbing tourism is increasingly valued by numerous countries, rock climbing tourism is a type of tourism that aims at rock climbing and provides sustainable tourism development for tourist destinations [3]. Starting from the developed countries such as Britain, the United States, Germany and France, this paper studies the development status, characteristics and economic value of rock climbing tourism. Because the previous researches on rock climbing tourism lacked the summary and comparative analysis among countries, this article analyzes the development characteristics of rock climbing tourism in developed countries. The development experience of rock climbing tourism in developed countries is practically significant for developing

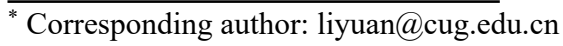

countries, such as promoting the innovation in the model of sports and tourism integration, helping rural economic transformation and promoting the rapid development of rock climbing tourism industry.

\section{Development of rock climbing tourism in various countries}

\subsection{United Kingdom}

Britain is the birthplace of outdoor sports, with access to 400 natural rock areas. As one of the traditional British outdoor sport, rock climbing has a broad base of participation. At present, at least 1 million rock climbing enthusiasts participate in the sport yearly. The rock climbing tourism industry flourished in the 1930s and became one of the fastest growing forms of outdoor leisure tourism at the end of the twentieth century.

Rock climbing tourism is an important part of tourism in the United Kingdom. As early as 2000, rock climbing and mountaineering "holiday activities" had generated 81.7 million pounds in revenue [4]. With recent increase in national leisure time, family participation in British rock climbing has increased yearly, prompting major travel companies to actively develop rock climbing tourism businesses. In Explore-Share, the world's first online booking platform for alpine adventures, travel agents have published route information for various UK holiday rock climbing tours which not only benefit these agents, but also promote the economic growth of related industries of the climbing destination, and expand the publicity effect of the destination. Moreover, the 
integration of rock climbing events with local characteristic activities has directly promoted the development of the regional economy. In Sheffield, the Cliffhanger outdoor festival features the finals of the British Rock Climbing Championships, which attracts rock climbers for technical exchanges and sightseeing, the data shows that in 2018, this attracted 40,000 live visitors and 270,000 online spectators, which directly promoted the development of related local industries [5].

\subsection{United States}

According to a survey conducted by the American Outdoor Foundation, participation in outdoor recreation among American citizens has reached 50\% (approximately 160 million people) in recent years, of whom more than 7 million participated in rock climbing in 2017 [6]. At present, the United States includes almost 30,000 accessible natural rock wall areas, the large participation in outdoor recreation and the classic rock climbing destinations across the United States have promoted the development of rock climbing tourism. Rock climbing in the United States can be traced back to the 1930s. The introduction of European rock climbing technology sparked a rock climbing frenzy in Yosemite. Since 1960, the proportion of rock climbing in the outdoor leisure travel market in the United States has increased year by year.

Rock climbing tourism has become an important driving force for the sustainable economic development of mountainous areas in the United States and an important part of the growing outdoor tourism economy. In 2017, the US rock climbing tourism market was valued at US\$12.45 billion, $87 \%$ of which was due to transportation and accommodation expenses, constituting a substantial part of the destination's economy [7]. In the three counties of New River Gorge, West Virginia, have 120,000 visits by out-of-town rock climbers visits each year, creating an US\$12.1 million in value for the local area and providing 168 jobs (Table 1), with the largest impact on jobs related to the catering and retail industries, providing 67 and 44 jobs, respectively [8].

Table1. Impact of rock climbing tourism on the regional economy in the USA

\begin{tabular}{|c|c|c|c|c|c|c|}
\hline Region & $\begin{array}{c}\text { Climber } \\
\text { visits }\end{array}$ & $\begin{array}{c}\text { Climber } \\
\text { consumption }\end{array}$ & Output & $\begin{array}{c}\text { Value } \\
\text { added }\end{array}$ & $\begin{array}{c}\text { Labor } \\
\text { income }\end{array}$ & Jobs \\
\hline $\begin{array}{c}\text { Red River Gorge, Kentucky } \\
(2002)\end{array}$ & 5,000 & $\$ 1,000,000$ & & $\$ 307,318$ & $\$ 185,455$ & 14 \\
\hline $\begin{array}{c}\text { 6 counties in the Red River } \\
\text { Gorge, region of Kentucky (2017) }\end{array}$ & 7,500 & $\$ 3,811,110$ & $\$ 2,905,217$ & $\$ 1,458,470$ & $\$ 826,352$ & 41 \\
\hline $\begin{array}{c}3 \text { regions in South Tahala and } \\
\text { Pisgah National Forest in North } \\
\text { Carolina (2017) }\end{array}$ & 200,000 & $\$ 13,848,000$ & $\$ 11,569,260$ & $\$ 6,797,251$ & $\$ 4,066,536$ & 170 \\
\hline $\begin{array}{c}\text { 5 regions in Chattanooga, } \\
\text { Tennessee (2018) }\end{array}$ & $\begin{array}{c}16565 \\
\text { non-local } \\
\text { climbers }\end{array}$ & $\$ 10,300,000$ & $\$ 6,964,056$ & $\$ 4,104,940$ & $\$ 2,508,310$ & 83 \\
\hline $\begin{array}{c}\text { 3 counties in the New River } \\
\text { Canyon Gorge, West Virginia } \\
(2019)\end{array}$ & $\begin{array}{c}120000 \\
\text { non-local } \\
\text { climbers }\end{array}$ & $\$ 12,108,000$ & $\$ 14,848,631$ & $\$ 9,025,779$ & $\$ 6,308,631$ & 168 \\
\hline
\end{tabular}

Note: The economic impact of rock climbing tourism in the United States is usually calculated using the IMPLAN (inputoutput) model, which includes eight indicators. The commonly used economic indicators are labor income, jobs, value added, and output. Labor income refers to the estimated income paid to workers due to the consumption output in the study area; value added refers to the regional net production value, including labor income, indirect business tax, and other property income after deducting operating costs. The output refers to the regional net value of production plus production costs, that is, the expenditures of rock climbers in the study area. Such expenditures are equivalent to the total cost of rock climbing, including but not limited to the research area. For example, the total expenditure of 7,500 rock climbers in the Red River Canyon is $\$ 3.81$ million, but the six studied counties in the Red River Canyon accounted for only $\$ 2.9$ million; thus, the output is $\$ 2.9$ million.

\subsection{Germany}

Germany is one of the birthplaces of rock climbing, and Saxon Switzerland in the southeast is also called the "cradle" of "free climbing". There are currently nearly 400 natural climbing areas (covering more than 4,000 rock walls and towers) in the country. Moreover, Germany has the largest consumer market for outdoor sports in Europe, and outdoor activities such as rock climbing and hiking are popular among German residents, in 2018, more than
500,000 people participated in rock climbing. Since 1991 , Germany has regularly held major events such as the World Cup of Rock Climbing and European Rock Climbing Championships. The long tradition of rock climbing and the strong climbing culture have promoted the development of German rock climbing tourism to be at the forefront of the world.

Rock climbing tourism accounts for a relatively high proportion of outdoor sports tourism in Germany. The German climbing tourism consumption model is dominated by family participation, and participants are mostly high-income families. Households with a monthly 
income of $€ 3,200$ or more account for approximately $60 \%$ of participants. In the Frankenjura region, rock climbing has become the main motivation for tourists to visit the region; the daily cost of climbing for the average overnight tourist (at least one night) is $€ 18.38$, and this daily cost of the average day-trip tourist is $€ 8.77$, tourists contribute $€ 1.75$ million to the local economy [9].

\subsection{France}

France is the birthplace of modern bouldering, with some 2,000 climbing areas, and the development of adjustable wooden climbing walls in France during the 1950s greatly promoted the development of domestic rock climbing. The number of French rock climbing participants was around 800,000 in 1993, and more than 2 million in 2018.

In France, rock climbing tourism was first regarded as a driver of economic growth, which contributed to the diversification and structural adjustment of the tourism economy. The development of new destinations improved the seasonal problems associated with rock climbing tourism and promoted tourist diversification. An early economic impact study showed that rock climbing tourism could result in economic growth of $€ 230,000, € 190,000$, and $€ 150,000$ to the Verdon Gorge, Southern Ardèche, and Orpierre regions, respectively. Rock climbing tourists typically spend their money on food and beverage establishments, such as bakeries cafes, bars, and small restaurants; in terms of accommodation, rock climbers typically prefer simple accommodation options, such as campsites, cabins, and youth hostels.

\section{Development characteristics of rock climbing tourism}

\subsection{Coordinated promotion by government and industry}

Active cooperation between government and industry has been a core driving force in the rapid development of rock climbing tourism, rock climbers are highly dependent on industry associations, and the addition of government resources is helpful for the climbing association to establish regional coordinated development mechanisms. The organization in the US rock climbing industry is based on volunteer service and oriented toward cooperation with land managers, while working to provide direct benefits to members, such organizations can also provide broader benefits to the entire rock climbing community. To protect natural rock wall resources, the German Mountaineering Association, the Federal Rock Climbing Association, and the German government's Nature Conservation Agency created the concept of "Joint Climbing" to promote the sustainable development of rock climbing in the Frankenjura region by defining a rock climbing code of conduct and displaying the strength of the walls in zones. In Swiss, the Rock climbing Association for Development (RAD) cooperates with local governments to help rural communities develop rock climbing resources, develop tourism to contribute to sustainable economic growth, and promote green climbing awareness through measures such as restricting access and protecting the environment.

\subsection{Destination management based on the climbing community}

In 2001, the World Wide Fund for Nature (WWF) issued the Guidelines for Community-based Ecotourism Development, which provided ideas for the development of rock climbing communities. In countries with relatively developed rock climbing tourism, rock climbing community is an important form of existence, its unified subculture provides climbers with a social space extending from the real experience to the exchange of rock climbing skills, and the mobility of its existence promotes frequent climbing trips. In the United States, community-based outdoor rock climbing management has achieved a balance between rock climbing activities, biodiversity, and ecological protection. Research by the Access Fund has revealed that rock climbing communities have played positive roles in ecological environmental education and in improving climbing behavior. In Italy, festivals and special events rooted in the climbing community, such as music festivals and Rocktoberfest (a rock climbing and beer festival), have further enhanced the sense of belonging of climbers to the destination and has attracted more climbing tourists.

\subsection{Development of destinations through improvements in infrastructure}

Infrastructure construction significantly improves the accessibility of the natural resources of the destination and stimulates the growth of rock climbing tourists. The infrastructure of a rock climbing destination includes convenient transportation, comfortable accommodation, safe and convenient climbing routes, catering facilities, outdoor equipment stores, and climbing guides, etc., which are usually provided by private individuals, local governments, accommodation providers, climbing associations or other related agencies. In the UK, the Idwal Lodge in Wales and the Black Sail Lodge in the Lake District were constructed close to climbing areas as early as the 1930s to address the problem of scarce rock climbing accommodation. In France, the climbing club in Verdon Gorge (part of FFCAM) works with local practitioners to provide training places and easy access routes for beginners. In the United States, information distribution facilities and resources, such as brochures, posters, bulletin boards, and information kiosks, have served important roles in the infrastructure of climbing destinations according to the Access Foundation's Climbing Management Guide.

\subsection{Raising of environmental awareness through outdoor rock climbing education}

Environmental education and proper supervision and management are crucial to protecting the natural environment of rock climbing. Climbing education can be used to help climbers to understand climbing rules through 
climbing guides, climbing media, destination information boards, road signs, codes of conduct, and training by industry entities (the content of climbing education may vary between destinations. Moreover, climbing ethics differ between countries, which also affects the content of climbing education.) In 1997, the German Natural Environment Council added a climbing education link to its teaching and training courses. In the UK, climbing education has included a focus on environmental sustainability, based on the contents of a climbing manual. Document 41 of the US National Park Service notes that "the field of climbing education and environmental impact monitoring are climbing an important part of the management project." US national parks have now flexibly implemented monitoring plans based on local conditions.

\subsection{Integrated development of rock climbing tourism and the Internet}

Online media has played an important role in the popularization of rock climbing. The Internet can be used to exchange rock climbing experience and skills and to promote the sale of rock climbing equipment. Moreover, using the internet to create the star power of professional rock climbers can promote the wider dissemination of rock climbing destinations among the public. Many online forums, such as Climb Find, Crag Notes, BMC Media Center, Meetup, and the World Rock Climbing Database, where climbers exchange experiences and share destination-related information. In 2018, YouTube videos published by the IFSC were viewed 7.7 million times, and Instagram was the IFSC's fastest-growing social media channel among all platforms.

\section{Conclusions}

The nature-based rock climbing tourism industry represents an increasingly popular market niche, which can greatly affect the local economy. Beginning in the early 1890s, after continuous development, the development model of rock climbing tourism has gradually formed a rock climbing community as the development unit, with government coordination and industry association promotion as the main organizational system. In addition, the developed countries have taken scientific and reasonable management measures in the aspects of rock climbing infrastructure construction, rock climbing education and Internet integration development to realize the sustainable development of rock climbing tourism. In order to expand the source of economic income in rural mountainous areas and rapidly develop the rock climbing tourism industry, developing countries should learn from the experience of developed countries, establish a coordinated management mechanism between the government and industry associations, increase investment in infrastructure construction, and attach importance to the fitness, leisure and economic value of rock climbing tourism.

\section{Acknowledgments}

The project of the Mountaineering Management Center of the State Sports General Administration (CMA2019-AC06).

\section{References}

1. Dimitriou, C.K. (2017) From theory to practice of ecotourism: Major obstacles that stand in the way and best practices that lead to success.Euro J Tour Hosp Rec, 8(1):26-37.

2. IFSC. (2020) Key Figures. https://www.ifscclimbing.org/index.php/about-us/key-figures.

3. Albayrak T, Caber M. (2016) Destination attribute effects on rock climbing tourist satisfaction: An asymmetric impact-performance analysis. Tour Geogr, 18(3): 280-296.

4. Coalter F, Dimeo P, Morrow S, et al. (2010) The benefits of mountaineering and mountaineering related activities: A review of literature: A report to the mountaineering council of Scotland. University of Stirling, Stirling.

5. Sheffleld BID. (2018) Delivering change togetherSheffield Bid Annual Report 2017/18. https://cdncms.f-

static.net/uploads/3259032/normal_5ebecf2295da $0 . p d f$.

6. OIA. (2020) 2019 Outdoor participation report. https://outdoorindustry.org/resource/2019outdoor-participation-report/.

7. Maples J N, Sharp R L, Clark B G, et al. (2017) Climbing out of poverty: The economic impact of rock climbing in and around eastern Kentucky's Red River Gorge. J Appalach Stud ,23(1): 53-71.

8. Maples J, Bradley M, Giles S, et al. (2019)Climbing out of coal country: The economic impact of rock climbing in West Virginia's New River Gorge. J Appalach Stud,25(2): 184-201.

9. Nickl S. (2009) Regionalökonomische effekte des klettertourismus in der Fränkischen Schweiz. Mitteilungen der Fränkischen Geographischen Gesellschaft,56(1):203-220. 